\title{
医療と福祉における複合材料の利用技術一IV. 自己組織化機構による骨・軟骨系複合材料の開発
}

\author{
一バイオミメティックス法一
}

\author{
生駒 俊之*, 田中 順三**
}

\section{1. はじめに}

日本は世界に類を見ない高齢化社会に突入し，特に医 療福祉の改善・発展が期待されている. 高齢化にともな い, 骨がもろくなる・軟骨が磨り減るなど我々の日常生 活に重篤な疾患が報告されている。これらの疾患には， 自家組織移植・モザイクプラスティーなど自分の正常組 織を切り取って疾患部位に移植するなどの手術が行われ ている。しかし，移植するには，その大きさの限界，正 常組織からの採取・移植にかかる時間, 正常組織を採取 したことによる痛みなど患者のQOL (quality of life ; 生活の質）の低下が大きな課題となっている.

自家組織の移植で対応できないような大きな欠損や疾 患の治療には, 現在, 人工材料が用いられている。たと えば, 加重のかかる部位である股関節の大棴骨治療に は，金属（ステンレス・チタン合金）やセラミックス(ア ルミナ; $\left.\mathrm{Al}_{2} \mathrm{O}_{3}\right)$ などの材料が用いられる ${ }^{1)}$.また過重の あまりかからない部位では, 骨と直接接合するハイドロ キシアパタイト $\left(\mathrm{Ca}_{10}\left(\mathrm{PO}_{4}\right)_{6}(\mathrm{OH})_{2}\right)$ ・リン酸三カルシウ 厶 $\left(\mathrm{Ca}_{3}\left(\mathrm{PO}_{4}\right)_{2}\right)$ などの焼結体 ${ }^{2)}$ が用いられている。しか し, 強度の違いによる生体骨の破壊, 材料から溶け出す 有害イオンによる痛み, 周辺組織と人工材料の親和性の 問題による緩みなどが問題となっている.

近年, 医工学の急速な進歩は, 再生医療といった新し い技術を生み出した. 1993 年に Langer と Vacanti が最 初にティッシュ・エンジニアリングの概念を提唱した ${ }^{3)}$. これは人工材料に細胞や生理活性物質を複合化させ, 生 体組織を in vitro（生体外）で再生させる試みである．彼 らは合成吸収系（ポリグリコール酸とポリ乳酸の共重合

* Toshiyuki IKOMA：物質 ・材料研究機構生体材料研 究センター（305-0044 つくば市並木 1-1）

** Junzo TANAKA：物質 - 材料研究機構生体材料研究 センター（305-0044つくば市並木 1-1）
体）に牛胎仔軟骨細胞を付着させ, 培養・増殖した後, その複合体を軟骨欠損部位に移植し, 硝子軟骨組織の再 生に成功した ${ }^{4)}$.これまでの研究から再生医療には, 細胞 の足場材・生化学的因子・学的因子などが重要である ことが提唱され, 広範囲にわたる分野で研究開発が行わ れている. 特に細胞の足場材の開発では, 細胞との接着 性 - 親和性, 生体内吸収性, 生化学的因子と材料の結合 性などの改善が必要とされている.

再生医療における細胞の足場材には, コラーゲン・多 糖類などの生体高分子やポリ乳酸・ポリグリコール酸な どの合成高分子が用いられている5). 上述した問題点を 克服するためには, これまでに使われている素材を上手 に複合化し，その特性を生かした材料設計が必要であ る. 本稿ではバイオミメティックス法と自己組織化機構 により, 生体組織に近い組成・構造を持った複合材料の 開発に関して我々の最新の知見を交えながら考えてみ たい.

\section{2. パイオミメティックス法6)}

バイオミメティックス法とは“自然から得たアイデア をより進んだテクノロジーに応用する”概念である。こ の研究の基盤となるのは, バイオミネラリゼーションと いつた “生体が溶液中で無機イオンを固体に変換するプ ロセス”であり,そこには必ず, “有機相と無機相が緊密 な関係を持つプロセス”がある. 我々は生体材料を開発 する際に自然界からどのようなアイデアを材料設計に応 用すればよいのだろうか。

骨は皮質骨（緻密骨）と海綿骨とに分類される。皮質 骨は骨の外側に, 海綿骨はつねに内側に存在する. 皮質 骨は，水分 (15\%)，ハイドロキシアパタイト $(50 \%)$, I 型コラーゲン $(30 \%)$ と多梼類（5\%）により構成され る7). その構造は, $67 \mathrm{~nm}$ の縞模様の周期を持ったコラー ゲン原繊維が一方向に整列し,さらにその周りにハイド 
ロキシアパタイトの微結晶が $c$ 軸に配向した階層構造 を持っている。この秩序だった構造のため，骨は“しな やか”で“硬い”機械的特性を持っている.

一方，軟骨は繊維の種類・量によって硝子軟骨・弾性 軟骨・繊維軟骨に大別される，軟骨組織は，多くの水分 (73\%) を保持し，タンパク質である II 型コラーゲン (10\%) とグリコサミノグリカン $(\mathrm{GAG})$ と呼ばれる多糖 類（コンドロイチン硫酸・ケラタン硫酸・ヒアルロン酸 など；14\%)により形成されている7).また，無機質 (3\%) はほとんど含まれていない，軟骨細胞はこの細胞外マト リックス (ECM) と呼ばれる複雑な構造をもった基質に より囲まれている。この複雑な構造のため高い含水率と 軟骨細胞への栄養素の供給を行い, 軟骨特有の “粘弾性 特性”と“低摩耗性”を保っている。

我々の身体は無機物と有機物から成る複雑な構造から 積み上げられ，実に巧みに高機能性を実現している。こ の複雑な構造を形成している過程を工学的な視点から考 えてみる、これら細胞外マトリックスの素材（コラーゲ ン・多糖類など）は細胞内で作られ, 細胞外に産出され る.そこで, 各素材が自己組織化的に整列し, 複雑な構 造を作り出している.この生体内でのメカニズムは, 実 際には微量な有機成分や無機イオンなどが関与し複雑で あるが，実際の合成にフィードバックするために簡略化 した合成系を考える必要があろう。つまり，素材を提供 する順序・pH・温度・イオン強度などを制御すれば生体 組織と類似した構造・組成を持った無機・有機複合材料 の設計が可能であると考えられる。

\section{3. 自己組織化機構を用いた材料合成・ その微細構造 8}

細胞が日常行っている自己組織化による骨・軟骨系組 織の複雑な構造を完全に人工的に作ることは, 現時点で は難しい，そのため，2つのアプローチが考えられる.

（1）複合材料を生体内に移植して我々の身体の中で生体 組織をつくらせる，（2）複合材料にあらかじめ細胞を播
種して生体組織をつくらせ，生体内に移植する（再生医 療)。後者の方法が現在注目され, 研究が進められてい る、いずれの場合でも材料の役割が大きく，新しい材料 の開発が急務である。一例として，骨・軟骨を修復する 材料の開発に関して述べる.

生体組織での石灰化では, リン酸カルシウムの一種で あるアパタイト (HAp) が形成される.この結晶は極め て小さな結晶（30〜 $50 \mathrm{~nm} ）$ であり，炭酸イオンを $8 \%$ 含んでいる、コラーゲン $(\mathrm{Col})$ は生体内に最も多く存在 するタンパク質で, 約 1,000 個のアミノ酸がペプチド結 合でつながっている.ポリペプチド鎖は左巻きのらせん 構造であり，その 3 本が組み合わさって右巻きのらせん 構造を作っている．つまりコラーゲン分子は複合三重ら せん構造である.コラーゲン分子の大きさは $300 \times 1.5$ $\mathrm{nm}$ であり，コラーゲン繊維は $67 \mathrm{~nm}$ 周期の縞模様が観 察される。これは，コラーゲン分子が $1 / 4$ 周期ずれて整 列しているためである。一方，軟骨組織に豊富に存在す

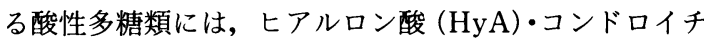
ン硫酸 $(\mathrm{ChS})$ が存在する。これらの 2 次構造の模式図

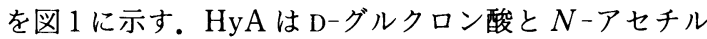
$\mathrm{D}$-グルコサミンの 2 糖鎖の繰り返しにより構成され，側 鎖にカルボキシル基をもっている．また ChS は，D-グ ルクロン酸と $N-$ ア チル D-ガラクトサミンの 2 糖鎖 の繰り返しにより構成され，側鎖に硫酸基とカルボキシ ル基をもっている.これらはグリコサミノグリカン （GAG）と呼ばれ，生理条件下では負に帯電している. このため, 生体組織の石灰化に重要な役割をしていると 考えられている.

図 2 に様々な素材を複合化する方法の模式図を示す。 この方法は 2 段階の反応により構成されている．最初に $\mathrm{HAp} /$ 多糖類複合体を作成し，さらに2 段階目の反応で コラーゲンを複合化させる．コラーゲンの複合化は恒温

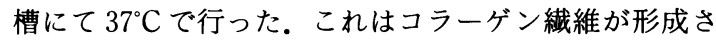
れ，複合体の強度を向上させることが期待される。アパ タイトと多糖類とコラーゲンの割合は, 60,25 と $15 \mathrm{wt} \%$
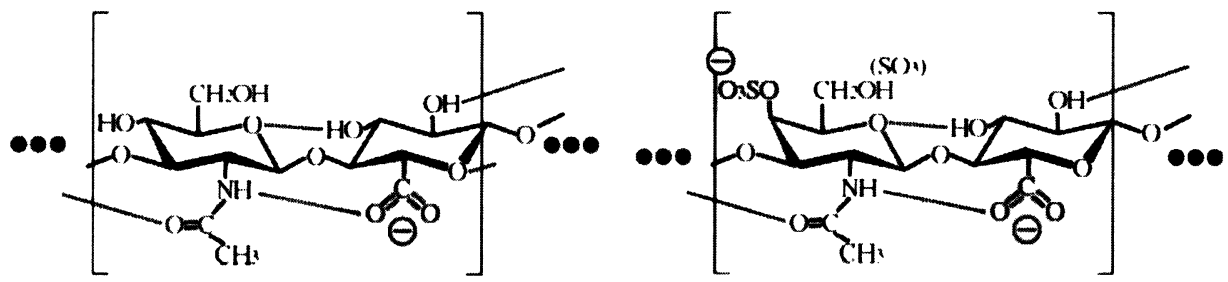

図 1 グリコサミノグリカンの例

左：ヒアルロン酸, 右：コンドロイチン硫酸 


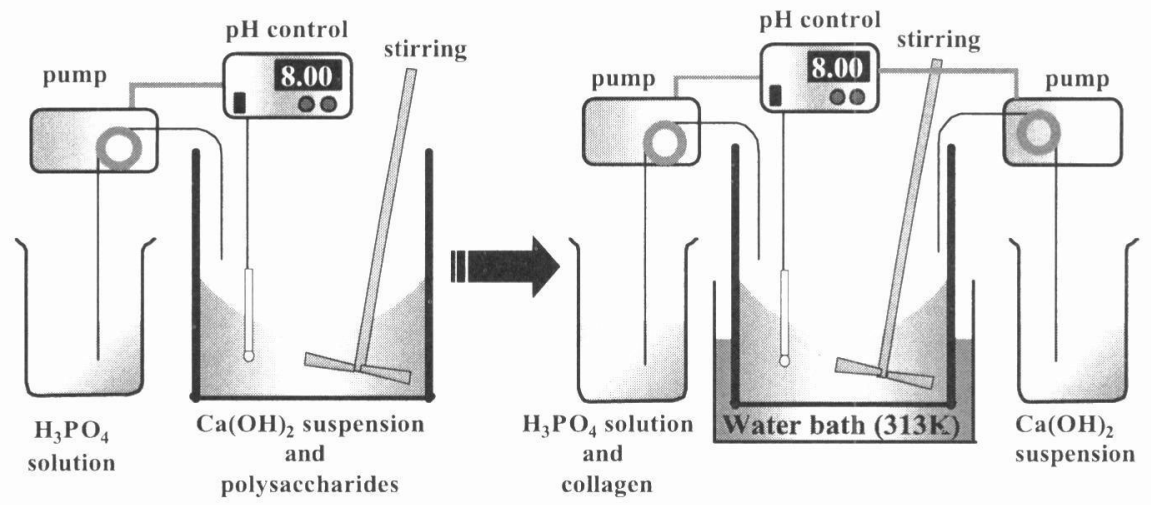

図 2 合成模式図

左：アパタイトと多糖類の複合材料の合成法, 右：アパタイト/多糖類自己組織化

体とコラーゲンの複合化方法

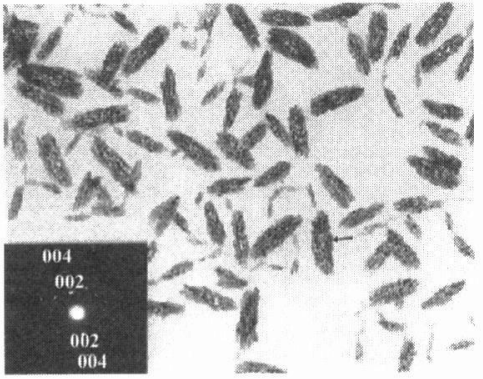

$-100 \mathrm{~nm}$

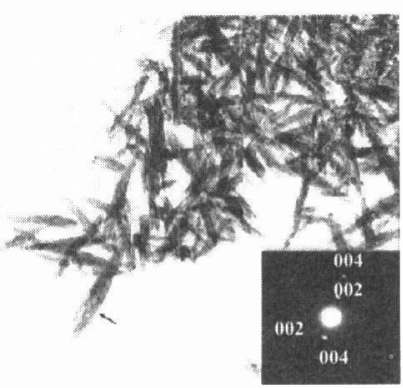

$-100 \mathrm{~nm}$

図 3 合成したアパタイト/多糖類自己組織化体の透過型電子顕微鏡 左：アパタイト/コンドロイチン硫酸自己組織化体, 右：アパタイト/ヒア ルロン酸自己組織化体, 電子線回折測定の結果から,一つの小さな凝集体 中でアパタイト微結晶が長軸方向に整列している

にて合成を行った。この方法により，HAp/ChS/I 型コ ラーダン $(\mathrm{I}-\mathrm{Col}) ・ \mathrm{HAp} / \mathrm{HyA} / \mathrm{I}-\mathrm{Col} \cdot \mathrm{HAp} / \mathrm{HyA} / \mathrm{II}$ 型コ ラーゲン $(\mathrm{II}-\mathrm{Col}) \cdot \mathrm{HAp} / \mathrm{HyA} / \mathrm{II}-\mathrm{Col} の 4$ 種類の複合体 を合成した。

図 3 に HAp/多糖類複合体の透過型電子顕微鏡像（以 下，TEM）を示す．HAp/コンドロイチン硫酸複合体で は，アパタイト微結晶の凝集体（大きさ $150 \times 50 \mathrm{~nm}$ ）が 観測される、またアパタイト/ヒアルロン酸複合体でも, 同様な凝集体（大きさ $300 \times 30 \mathrm{~nm}$ ）が観測される。一つ の凝集体加ら電子線回折測定を行った結果，アパタイト の (002) と (004) の回折線がスポット状に観測される. これは,アパタイト微結晶の $c$ 軸が凝集体の長軸方向に 整列していること示している。このようなアパタイト微 結晶の整列は, 多糖類を水酸化カルシウム懸濁液に添加 して合成したときに自己組織化的に生じている.
図 4 亿各複合体の格子像を示す。矢印で示した方向に 対して垂直に $0.34 \mathrm{~nm}$ の間隔の縞模様が観測される.ア パタイト微結晶のカルシウム密度が高い部分が縞状に観 測されている。自己組織化機構の詳細に関しては 5 節で 述べる，得られたアパタイト微結晶の大きさは，20×5 $\mathrm{nm}$ の板状結晶であった。

図 5 に一軸圧縮法により圧力を $40 \mathrm{MPa}$ かけて成形し た HAp/ChS/II-Col 複合体を示す. 合成直後の複合体は 大量に水を含んでいる。このため成形する時に脱水・圧 縮を同時に行う。図に一例を示したように得られた複合 体は，いずれも透明なものであった。

図 6 に HAp/ChS/II-Col 複合体を圧縮方向に垂直に 切断した断面の TEM 像を示す。図に示すように 0.34 $\mathrm{nm}$ の間隔の縞が観測される.これは,アパタイト微結晶 が圧縮方向に対して垂直に配向していることを示してい 

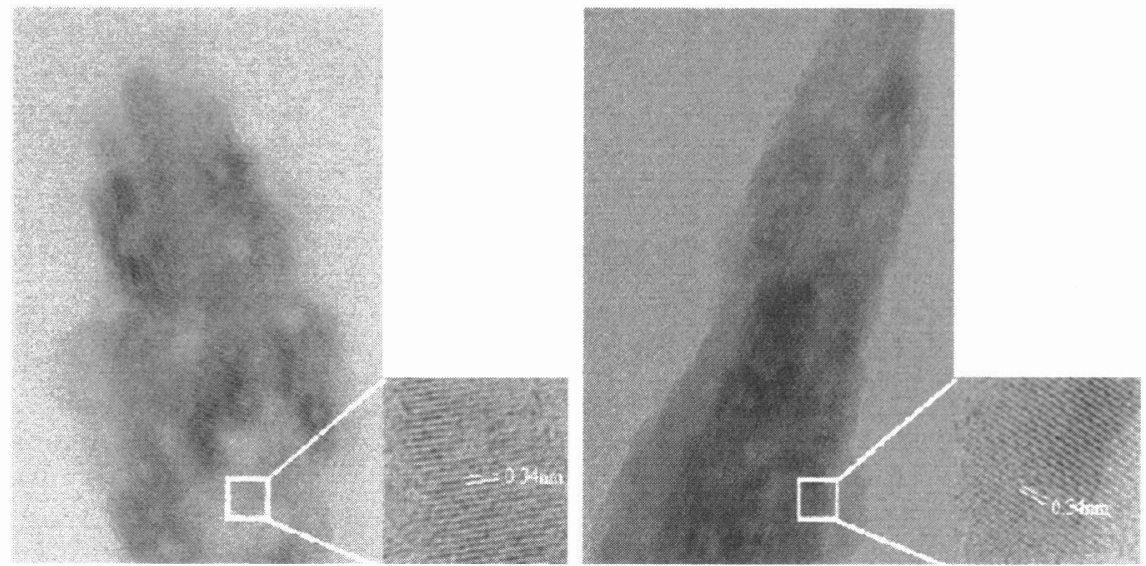

図 4 自己組織化体の格子像

左：アパタイト/コンドロイチン硫酸自己組織化体，右：アパタイト/ヒアルロン酸自己組織化体

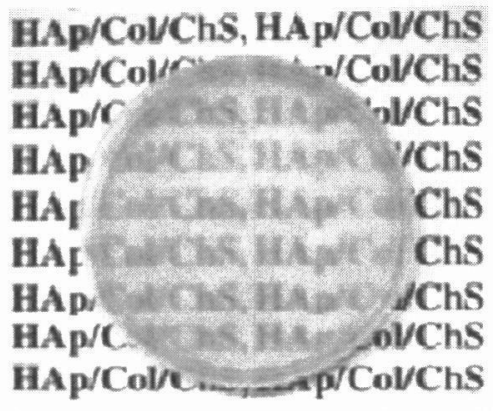

\section{$1 \mathrm{~cm}$}

図 5 成形したアパタイト/コンドロイチン硫酸/I 型コラーゲン複合体

る.また，成形体を粉砕した試料とそのままの成形体を 粉末 X 線回折 (XRD) 測定した結果, 粉砕した試料の場 合には002の回折線が観測されるが，成形体を測定した 場合は, 002 の回折線が観測されなかった。このことは, 成形体中でアパタイト微結晶の $c$ 軸が圧縮方向に対し て垂直に配向していることを示しており，TEM 観察の 結果と一致していた。

ここに示したように HAp/多糖類自己組織化を合成し てコラーゲン繊維を組み合わせ，一軸圧縮（脱水）を行 うことで階層構造を持った複合体の設計が可能であるこ とが示唆された。

これまでに皮質骨および軟骨の 3 点曲げ試験による機 械強度は 50〜150 MPa および 10〜 40 MPa である。ま た，これまでに臨床応用されている HAp 焼結体の機械

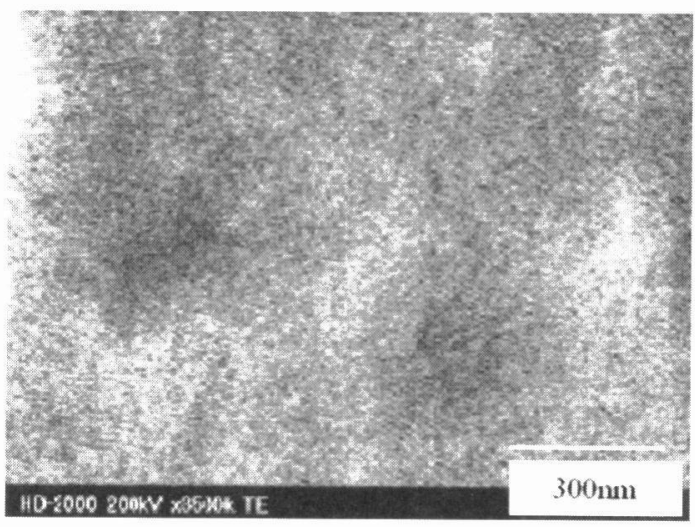

図 6 成形した複合体の断面透過型電子顕微鏡像 写真内に $0.34 \mathrm{~nm}$ 間隔の縞が観測される

強度は約 $100 \mathrm{MPa}$ である。今回合成した各複合体の機 械強度を 3 点曲げ試験を用いて行った。図 7 にそれぞれ の複合体の機械強度を示す。I 型コラーゲンを含む 3 成 分系の複合体は，II 型コラーゲンを含む複合体と比較し て明らかに強度が高いことが分かる。また， $\mathrm{HAp} / \mathrm{ChS} /$ I-Col 複合体は, $83 \mathrm{MPa}$ と骨に近い強度を持っているこ とが明らかとなった。I 型コラーゲンと II 型コラーゲン を含む複合体での強度の違いは，コラーゲン分子の繊維 形成能に依存していると考えられる.

\section{4. 自己組織化のメカニズム}

多段階的な反応機構における各段階での無機/有機複 合界面で生じている反応，特にアパタイト微結晶の自己 


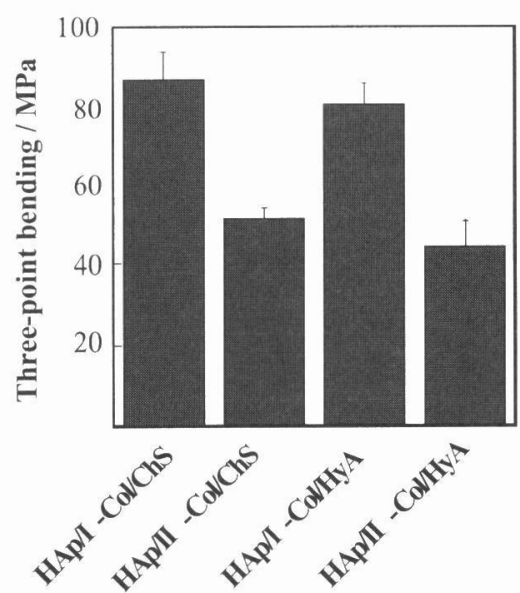

図 7 各複合体の三点曲げ試験結果

I 型コラーグンを含む複合体は II 型コラー ゲンを含む複合体と比較して強度が高い

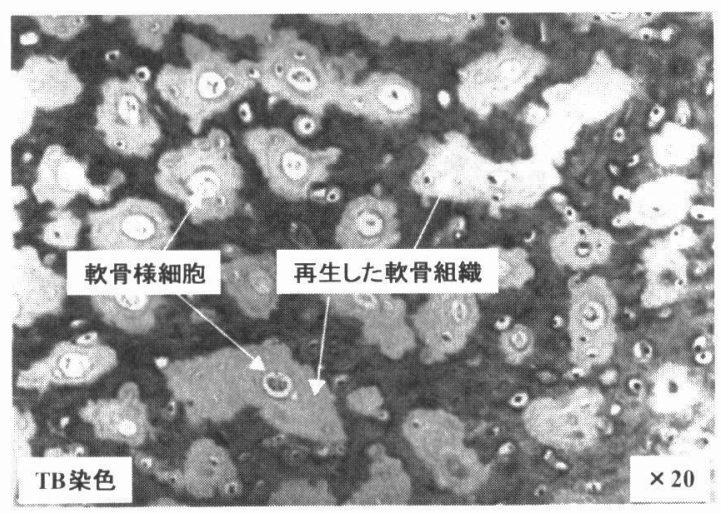

図 8 ラット・膝関節に移植した材料の光学顕微鏡 写真 ( $T B$ 染色)

組織化に関して考えてみる。水酸化カルシウム懸濁液中 に添加した多糖類のカルボキシル基は，アルカリ性溶液 中で解離してカルシウムイオンと結合していると考えら れる。このカルボキシル基と弱い配位結合により結合し たカルシウムイオンを核形成場として，リン酸基との反 応が生じアパタイトの沈着が生じる。このようなカルボ キシル基とのアパタイト結晶の相互作用に関してはこれ までに LB（Langmuir-Blogget）膜法により盛んに研究 されている.ここでは, 多糖類の 2 次構造(カルボキシル 基の配列）とアパタイト結晶のエピタキシャル的な成長 に関して述べる。

アパタイト結晶は $a=0.942, c=0.688 \mathrm{~nm}$ の格子定数 を持ち, 空間群・六方晶系に属する結晶である、アパタ

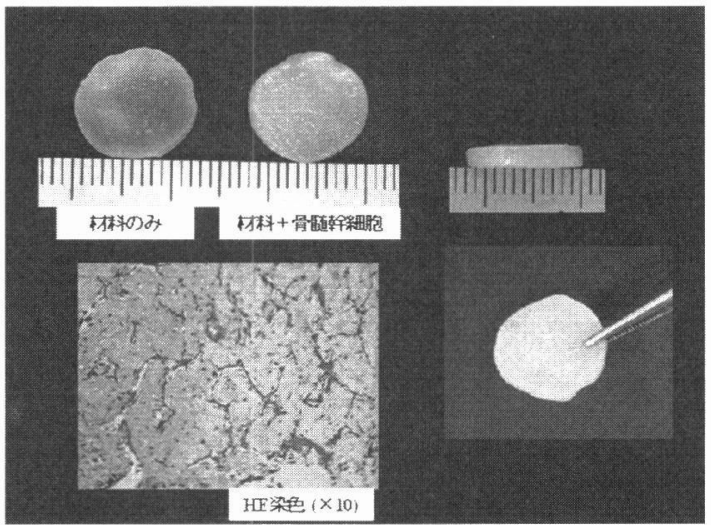

図 9 多孔質材料と in vitro 中で軟骨再建した軟骨 組織（細胞培養 2 週後）

イト格子中の水酸基は水酸コラムといわれる $c$ 軸上に 整列している，この周りにカルシウム三角形が $z=1 / 4$, 3/4のミラー面上に存在している。この隣り合うカルシ ウム三角形の $c$ 軸方向の距離は, 格子定数の半分の長さ である $(0.34 \mathrm{~nm})$ 。一般に， $a$ 面はカルシウムにより終 端しているため，正に帯電していると考えられている。 一方，多糖類は 2 糖鎖の繰り返し構造により形成されて いる. D-グルクロン酸の側鎖であるカルボキシル基の繰 り返しにより，アパタイトの核形成場となるカルボキシ ル基間の距離は約 $1.02 \mathrm{~nm}$ の間隔で整列している.この 距離は, アパタイト結晶の $c$ 軸長の 1.5 倍の距離 $(1.05$ $\mathrm{nm})$ とほほ一致している.このためアパタイト/多糖類の 自己組織化が生じたと考えられる。

\section{5. 複合体の生体内反応性}

$\mathrm{HAp} / \mathrm{ChS} / \mathrm{II}-\mathrm{Col}$ 複合体を軟骨組織に移植して生体の 応答を調べる実験を行った。図 8 に材料を家鬼の膝関節 に移植して 4 週後の結果を示す。材料内部に未分化の軟 骨様細胞が入っている様子が観測される。このように軟 骨様細胞が材料内部に入り込む現象は，他の材料では観 測されていない。さらに HAp/HyA/II-Col 複合体を多 孔質化させた材料にマウスの助軟骨の軟骨細胞を播種し て in-vitro の実験系により軟骨組織の再建を試みた。図 9 にその結果を示す。細胞を播種しない場合，トルイジ ンブルー染色により何も染色されない. 3 日後には青色 に軟骨細胞が染色されていることが分かる。ささら 1 週 後には軟骨細胞が生着でき, 2 週後には細胞外基質の産 生を行っていることが分かった。このように材料の微構 造を制御することで軟骨組織の再建の可能性が示唆さ 
れ, 軟骨細胞の分化・増殖に与える材料効果の解明が進 められている.

6. ま と め

軟骨・骨再生の研究は, 現在, 米国・日本において熾 烈な国際競争が繰り広げられている．ここ数年の組織工 学の進展は目覚しいものがあり, 多数の企業・機関にお いて軟骨組織の再生に対して成長因子・生体力学効果を 解明している．細胞の足場材に関しては，コラーゲン・ 乳酸系ポリマーなどが取り上げられ，多孔体を用いた研 究が進められている．軟骨組織に近い材料の研究はまだ 着手されたばかりであるが，今後，合成技術の開発・細 胞や組織に与える材料効果を解明することで新しい複合 機能材料が開発されると期待される.

この研究は, 東京医科歯科大学 (宗田教授・関矢助手) との共同研究として進められている，その研究結果の一 部を紹介した。
参 考 文 献

1）宮入裕夫：生体材料の構造と機能，養賢堂 (2001).

2）牧島亮男, 青木秀希:セラミックスサイエンスシリ ーズ 7, バイオセラミックス（山口＼cjkstart喬, 柳田博明 編)，技報堂出版(株)（1984）.

3) R. Langer \& J.P. Vacanti : Science, 260 (1993), 920-932.

4) C.A. Vacanti, R. Langer, B. Schloo \& J.P. Vacanti : Plast. Reconstr. Surg., 88 (1991), 753759.

5）再生医療と生命科学, 蛋白質 核酸 酵素, 共立出版, 2000 年 9 月増刊号 $(2000)$.

6）長田義仁編：バイオミメティックスハンドブック, エヌ・ティーエス(株) (2000).

7）須田立雄，小澤英浩，高橋栄明：骨の科学, 医歯薬 出版 (1995).

8) T. Ikoma, T. Muneta \& J. Tanaka : Key Eng. Mat., 192, 5 (2000), 487-490. 